\title{
Serum biochemical activities and muscular soreness in transported goats administered with ascorbic acid during the hot-dry season
}

\author{
Ndazo S Minka (1), Olusegun J Ayo (2)
}

(1) College of Agriculture and Animal Science, Division of Agricultural Colleges, Ahmadu Bello University, Mando - Kaduna, Nigeria; (2) Department of Physiology and Pharmacology, Faculty of Veterinary Medicine, Ahmadu Bello University, Zaria, Nigeria.

\begin{abstract}
The effects of handling, loading and $12 \mathrm{~h}$ of road transportation during the hot-dry season on muscular metabolism of 20 experimental goats administered orally with $100 \mathrm{mg} / \mathrm{kg}$ body weight of ascorbic acid (AA) dissolved in $10 \mathrm{ml}$ of sterile water, and other 20 control goats given equivalent of sterile water $40 \mathrm{~min}$ prior to transportation were investigated. The result obtained post-transportation showed that handling, loading and transportation were stressful to the goats, especially the control goats and resulted into muscular damage and the development of delayed-onset-muscular-soreness (DOMS), which may lead to dark-firm-dry (DFD) syndrome meat with undesirable effects on its quality. In the experimental goats administered AA such transportation effects were minimal or completely abolished. The result demonstrated that AA reduced the incidence of DOMS and muscular damage in transported goats, therefore it may be used to improve the welfare and quality of meat obtained from goats subjected to long period of road transportation under adverse climatic conditions.
\end{abstract}

Key Words: ascorbic acid; goats, muscular soreness, serum enzymes, transportation stress

European Journal Translational Myology - Basic Applied Myology 2010; 1 (4): 193-203

Pre-slaughter conditions of livestock causes complex psychological and physiological changes, induced by rounding-up, handling, loading, transportation, novelty of environment, long standing duration, social disorder, deprivation of food and water and the effect of adverse climatic conditions [26,29,34,39,40,52,54]. These factors can influence animal welfare and subsequent meat quality. Thus, the quality of meat in the market will largely depend on the pre-slaughter conditions of the animal $[17,26]$.

Substantial studies on the effects of transport stress on the welfare and meat quality of cattle, pigs, horses and poultry are reviewed by Knowles [33], Fazio and Fernazzo [16], Warriss [64] Broom [9], Ferguson and Warner [17], Gregory [23], but in goats such studies are still limited in the available literature.

Transportation of goats has expanded from Africa and Asia to the US and worldwide due to the increased demand in goat meat and skin, the latter being highly prized and used in leather industries [7,29,30,40]. The few studies conducted on transportation or preslaughter conditions of goats are done in temperate regions of the world where livestock is predominantly raised intensively [29,54]. Factors affecting goats transported by road in tropical countries are high ambient temperature (AT), relative humidity (RH) and intense solar radiation occurring during the hot-dry season of the year $[40,42,54]$. In addition, the majorities of goats in tropical regions are reared under extensive management systems and are difficult to handle. This compound the stress encountered during rounding-up, handling and loading, which have been established as the biggest stress factor during road transportation of animals [6,21,23,26,35,44].

During transportation, livestock are subjected to physical demands and the energy required to service this demands is enormous and this will have a negative impact on muscles metabolism. In addition, sudden, unaccustomed and exhausted stress or exercise, increase in oxygen uptake by skeletal muscles, and intense production of free radicals, reactive oxygen species (ROS), nitrogen oxygen species (NOS) and Etype prostaglandin release in circulation during stress has been reported to be the major cause of changes in muscle metabolism and delayed-onset-muscularsoreness (DOMS) which may result to dark-firm-dry (DFD) meat [10,11,23,28,29,38,53,62]. The muscles enzymes activities of creatine phosphate kinase (CPK), 


\section{Effect of ascorbic acid on muscles of transported goats}

European Journal Translational Myology - Basic Applied Myology 2010; 1 (4): 193-203

alanine aminotransferase (ALS), aspartate aminotransferase (AST), and glucose and urea have been shown to be elevated in many stressed animals during transportation and these enzymes are often used in assessing the extent of muscular damage and fatigue [26,28,29,34,50]. Transported animals that developed DOMS and muscular damage may develop dark-firmdry (DFD) meat, which is an undesirable meat quality $[10,11,28,29,63]$.

Intervention strategies towards alleviation of road transportation stress in animals have been proposed by administration of analgesic, neuroleptics, electrolytes or supplementing one or more dietary elements, before, during or after transportation [1,5,36,43,49,57]. In spite of some attenuating effects of some supplements, others are counter-productive, with greater consequential effects on both animals and humans, some have any effect and lack consistency and efficacy, while some are difficult to obtain and apply by the farmers $[17,20,48]$. There are not many researches aimed to know how to relieve road transportation stress in goats [20,40]. The identification of an additional agent cheaper, non-toxic, with no withdrawal time and easily administered is of great importance in the field of animal transport and meat quality.

Ascorbic acid (AA) is known to be the first vitaminergic neurotransmitter and a potent antioxidant vitamin that protect cells and tissues from oxidative stress and lipid peroxidation [8,31,62]. It has been shown to enhance animals' immunity and adaptational capability to environmental stress [41,42]. There is a reasonably body of evidence supporting the use of AA to reduce the duration of DOMS in humans and laboratory animals [12,27].

Even though ruminants rely on endogenous synthesis of AA from glucose and may not require supplementation in the diet, nevertheless, during stress, diseases or exercise, the requirement of AA may exceed the synthetic capacity of the liver. The supplementation of this vitamin in a moment of greatest need for the animal can be a potential reserve and an alternative treatment at low cost [14,25,37].

The present study was aimed at examining the effects of 12 hours of road transportation on muscle metabolism and the development of DOMS in goats raised extensively during the hot-dry season, and to suggest AA as an ameliorating agent against the development of DOMS and muscular damage in transported goats.

\section{Materials and Methods}

Experimental site and meteorological data from the study area

The study was conducted at the Livestock Farm, College of Agriculture and Animal Science, Ahmadu Bello University, Kaduna ( $\left.11^{\circ} 10^{\prime} \mathrm{N}, 07^{\circ} 38^{\prime} \mathrm{E}\right)$, which is located in the northern Guinea Savannah zone of Nigeria. The goats were transported during the hot-dry season (April) from Kaduna to Makera $\left(12^{\circ} 31^{\prime} \mathrm{N}, 06^{\circ}\right.$ $\left.11^{\prime} \mathrm{E}\right)$ and from Makera back to Kaduna, covering a total distance of $600 \mathrm{~km}$.

The meteorological data of the ambient temperature (AT), relative humidity (RH) and sunshine duration were recorded at the experimental site at 06:00, 13:00 and 18:00 h daily for 7 consecutive days before and after transportation. Values of these parameters were also recorded hourly during the $12 \mathrm{~h}$ transportation period which commenced at 7:00 and ended at 19:00 h, and after unloading the goats from the vehicle at the first, second and third h post-transportation. The AT and RH were measured using a wet- and dry-bulb thermometer (Cocet, Shenzhen-Guangdong, China).

\section{Animals and managements}

Forty Red Sokoto goats served as subjects of the study. The goats which included males and non-pregnant females, aged 2.5 to 3 years old and weighing between 23-25 kg were obtained from within the study area 3 weeks before the study commenced, and were housed in a standard goat pen measuring $10 \mathrm{~m}$ long by $5 \mathrm{~m}$ wide and $2.5 \mathrm{~m}$ high. The goats were not restrained inside the pen and were stocked at a rate of $1 \mathrm{~m}^{2} /$ goat [29]. They were herded out and grazed on an improved natural pasture from 09:00 to 18:00 h each day and were given access to drinking water ad libitum. The pasture on which the goats grazed was characterized by browse shrubs, shoots of guinea corn, maize and guinea corn residues, and groundnut hay. Three weeks to the transportation, the goats were prophylactically treated against ecto- and endo- parasites, and haemoprotozoals.

\section{Experimental design}

Two days before transportation, blood sample were obtained from the jugular vein of each goat to established baseline values. On transportation day before the journey, the goats were randomly allocated into experimental and control groups, each consisting of 20 goats. During handling, at 06:00 h before loading, ten goats from each group were blood sampled to obtain pre-loading baseline values. At the same time all the goats in the experimental group were administered ascorbic acid (AA) orally (Sigma Chemical, St. Louis, MO, USA) at a dose of 100 $\mathrm{mg} / \mathrm{kg}$ body weight [40,42], dissolved in $10 \mathrm{ml}$ of sterile water, while each of the control goats was administered orally $10 \mathrm{ml} /$ goat of sterile water. Goats that were blood sampled were coloured-marked for easy identification. Thereafter, they were then loaded into a vehicle. The handling and loading of the goats took about $40 \mathrm{~min}$. After loading, and just before the start of the journey blood samples were quickly obtained from the other ten goats in each group that had not previously been bled to determine the effects 


\section{Effect of ascorbic acid on muscles of transported goats}

European Journal Translational Myology - Basic Applied Myology 2010; 1 (4): 193-203

Table 1. Percent $(\%)$ number of the experimental $(n=20)$ and the control goats $(n=20)$ that developed various scores of delayedonset-muscular soreness pre- and post-transportation period.

\begin{tabular}{|c|c|c|c|c|c|c|c|c|}
\hline \multirow[b]{3}{*}{ Scores of muscular soreness } & & & \multicolumn{6}{|c|}{ Post-transportation period (h) } \\
\hline & \multicolumn{2}{|c|}{ Pre-transportation } & \multicolumn{2}{|c|}{12} & \multicolumn{2}{|c|}{36} & \multicolumn{2}{|c|}{60} \\
\hline & Experimental & Control & Experimental & Control & Experimental & Control & Experimental & Control \\
\hline 1 (no soreness) & $100^{\mathrm{a}}$ & $100^{a}$ & $70^{\mathrm{a}}$ & $0^{b}$ & $95^{a}$ & $50^{b}$ & $100^{a}$ & $90^{a}$ \\
\hline 2 (mild) & 0 & 0 & $30^{a}$ & $0^{b}$ & $5^{a}$ & $10^{b}$ & $0^{a}$ & $10^{b}$ \\
\hline 3 (moderate) & 0 & 0 & $0^{a}$ & $5^{a}$ & $0^{a}$ & $15^{b}$ & 0 & 0 \\
\hline 4 (severe) & 0 & 0 & $0^{a}$ & $15^{b}$ & $0^{a}$ & $25^{b}$ & 0 & 0 \\
\hline 5 (very severe) & 0 & 0 & $0^{a}$ & $80^{b}$ & 0 & 0 & 0 & 0 \\
\hline
\end{tabular}

Values along the same column with different superscript alphabets are significantly different $(\mathrm{p}<0.05)$

of handling and loading. The goats were then transported for $12 \mathrm{~h}$ on a tarred road from Kaduna to Makera, and from Makera back to Kaduna at a an average speed of $50 \mathrm{~km} / \mathrm{h}$. Food was withdrawn from the goats $6 \mathrm{~h}$ before transportation and throughout the $12 \mathrm{~h}$ journey, while water was withdrawn only during the journey period $[22,55]$.

On completion of the journey, the goats were returned to the same pen, offered feed and water and managed as it was done before their transportation. Immediately after transportation, $12, \quad 36$ and $60 \mathrm{~h}$ after transportation, all the goats in both the experimental and the control groups were blood sampled.

\section{Handling, loading and journey time}

The goats were humanely handled, loaded and transported in accordance with the guidelines governing animal transport welfare by road $[2,15,40,55]$. The loading of the goats was performed individually by two persons between 06:00 to 07:00 h. The rope was long enough for each animal to freely turn and lie down. The goats were stocked at a rate of $0.3 \mathrm{~m}^{2}$ per animal in an alternated pattern between the groups so as to provide similar condition to all the goats.

The journey commenced at 7:00 h and ended at 19:00 h. During the journey the vehicle travelled for $12 \mathrm{~h}$ on a typical Nigerian asphalt single lane road, from Kaduna to Makera town and then back to Kaduna, a total distance of $600 \mathrm{~km}$. The vehicle travelled at an average speed of $50 \mathrm{~km} / \mathrm{h}$ and it was driven by two drivers each in turn for $6 \mathrm{~h}$. In adherence to international transport welfare order the goats were rested for an hour after $8 \mathrm{~h}$ transportation period [2]. During the stop, the vehicle was parked in shade to avoid the direct effect of sunlight and rapid build-up of heat inside the vehicle [55].

\section{Evaluation of muscular soreness}

Muscular soreness of the goats was evaluated immediately, and 12, 36 and $60 \mathrm{~h}$ after transportation by palpation of the lumbar region and gluteus muscles. Assessment was based upon clinical observations involving appraisal of an apparent reluctance to move, stiffness of gait, and pain response upon palpation of the lumbar and gluteus muscles. A five point scoring system was used to score the muscular soreness with scores 1, 2, 3, 4 and 5 representing no soreness, mild, moderate, considerable and severe soreness, respectively $[19,38]$. Animals with any physical injury or abnormal swelling were exempted from the assessment.

\section{Blood collection and serum biochemical analysis}

During each blood sampling $5 \mathrm{ml}$ of blood were collected by venipuncture of the jugular vein of each goat using syringes without any anticoagulant. The collected blood samples were taken as quickly as possible to the laboratory, where they were kept at room temperature until the blood had clotted. Thereafter it was centrifuged at $3000 \mathrm{rpm}$ for $10 \mathrm{~min}$ and the serum content was kept at $-18{ }^{\circ} \mathrm{C}$ until analyzed, which was done within $24 \mathrm{~h}$ after each blood collection period at clinical laboratory. The serum concentration of glucose, ALT, AST, urea, and CPK were analysed using an automated analyzer (COBAS MIRA, Roche, Nutley, NJ, USA).

\section{Statistical analysis}

All data obtained were subjected to Student's t-test and Pearson's correlation analysis. Data were expressed as 


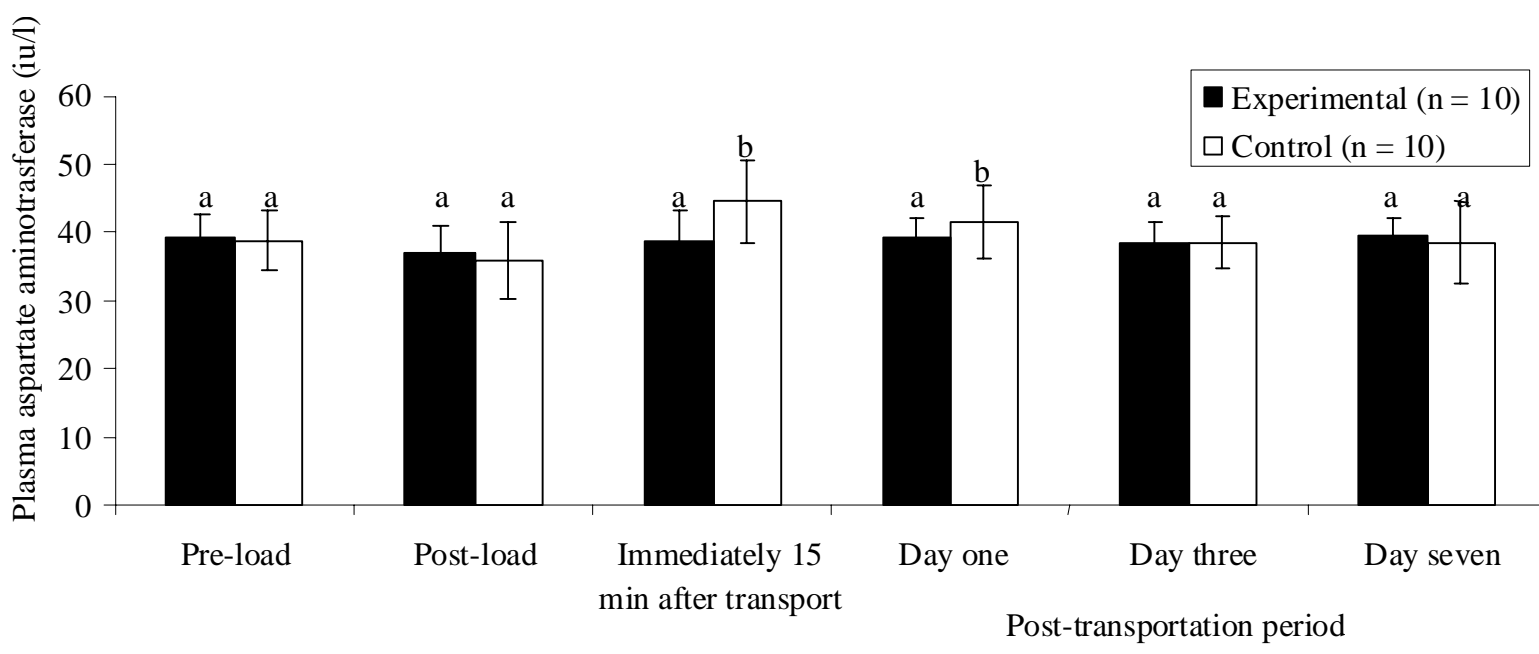

Fig. 1: Fluctuations in plasma aspartate aminotrasnferase (iu/l) activity in the experimental and the control goats preand post- transportation. $a, b=$ Bars with different alphabets are significantly $(P<0.05)$ different.

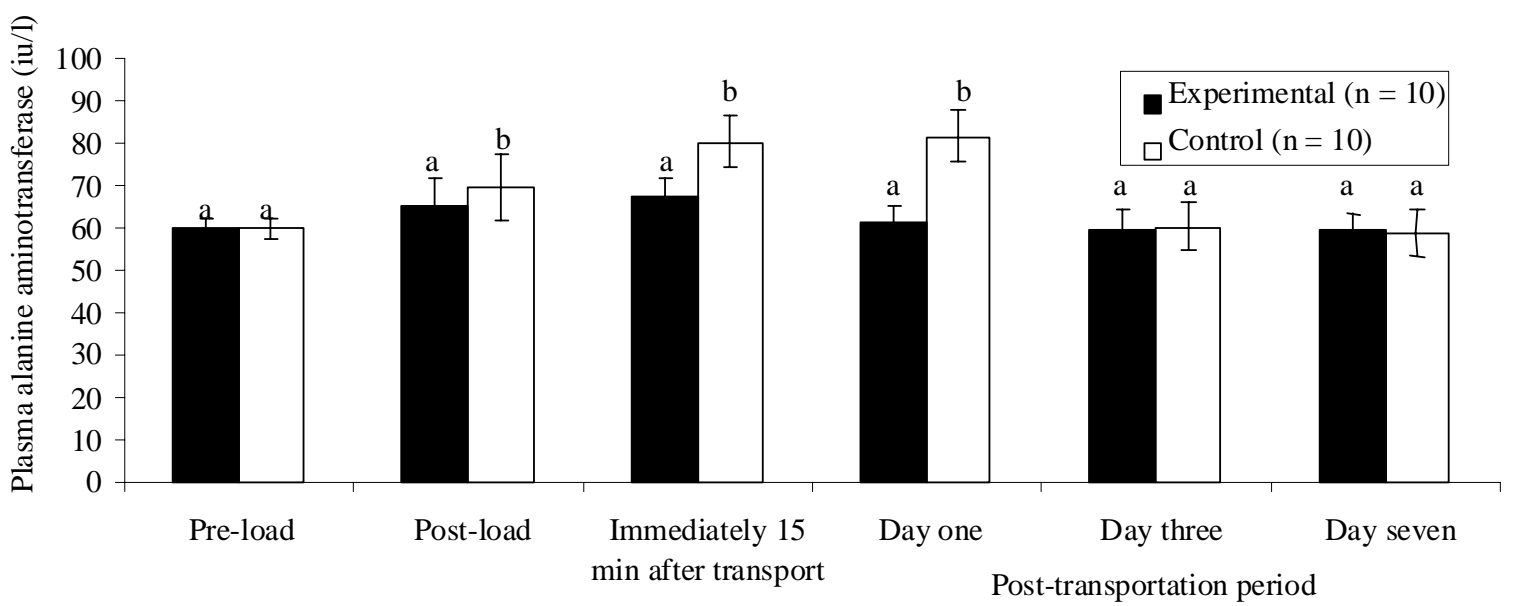

Fig. 2: Fluctuations in plasma alanine aminotrasnferase (iu/l) activity in the experimental and the control goats preand post- transportation. $a, b=$ Bars with different alphabets are significantly $(P<0.05)$ different.

mean \pm standard error of the mean (Mean \pm SEM). Values of $\mathrm{p}<0.05$ were considered significant.

\section{Results}

\section{Meteorological conditions}

The AT measured during the study period had a mean value of $36.7 \pm 0.2{ }^{\circ} \mathrm{C}$, with minimum and maximum values of $20.0{ }^{\circ} \mathrm{C}$ and $39.4{ }^{\circ} \mathrm{C}$ respectively. The $\mathrm{RH}$ values fluctuated between $65 \%$ and $75 \%$ with a mean value of $70.0 \pm 5.6 \%$. During transportation, especially in the hot afternoon period of the day, the AT inside the vehicle rose with the duration of the journey from $28.2^{\circ} \mathrm{C}$ to a maximum value of $40.1^{\circ} \mathrm{C}$ at $14: 00 \mathrm{~h}$. Thereafter it decreased to $34.0^{\circ} \mathrm{C}$ during the last hour of the journey. The mean AT recorded during the journey was $37.2 \pm 1.3{ }^{\circ} \mathrm{C}$, while the RH was $75.4 \pm$ $1.8 \%$. The sunshine duration on the day of journey was $12.5 \mathrm{~h}$. 


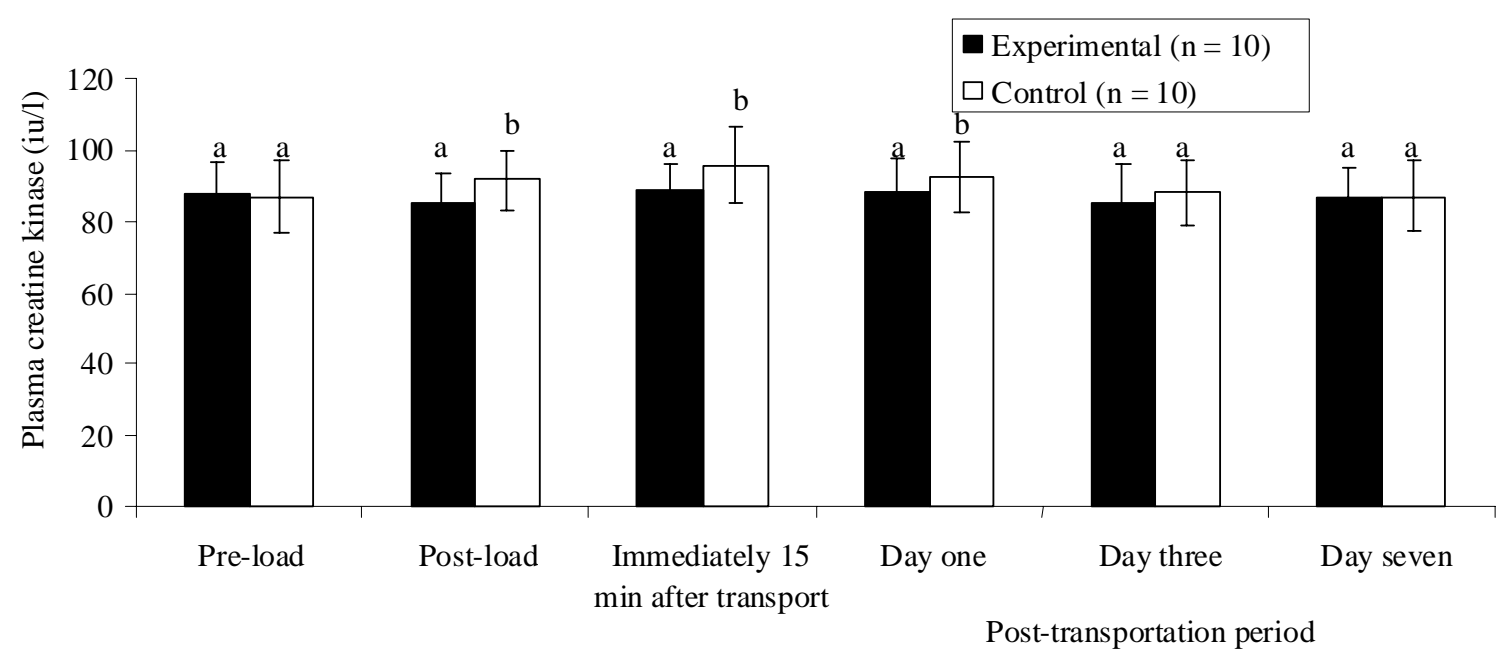

Fig 3: Fluctuations in plasma creatine kinase (iu/l) activity in the experimental and the control goats pre- and posttransportation. $a, b=$ Bars with different alphabets are significantly $(P<0.05)$ different.
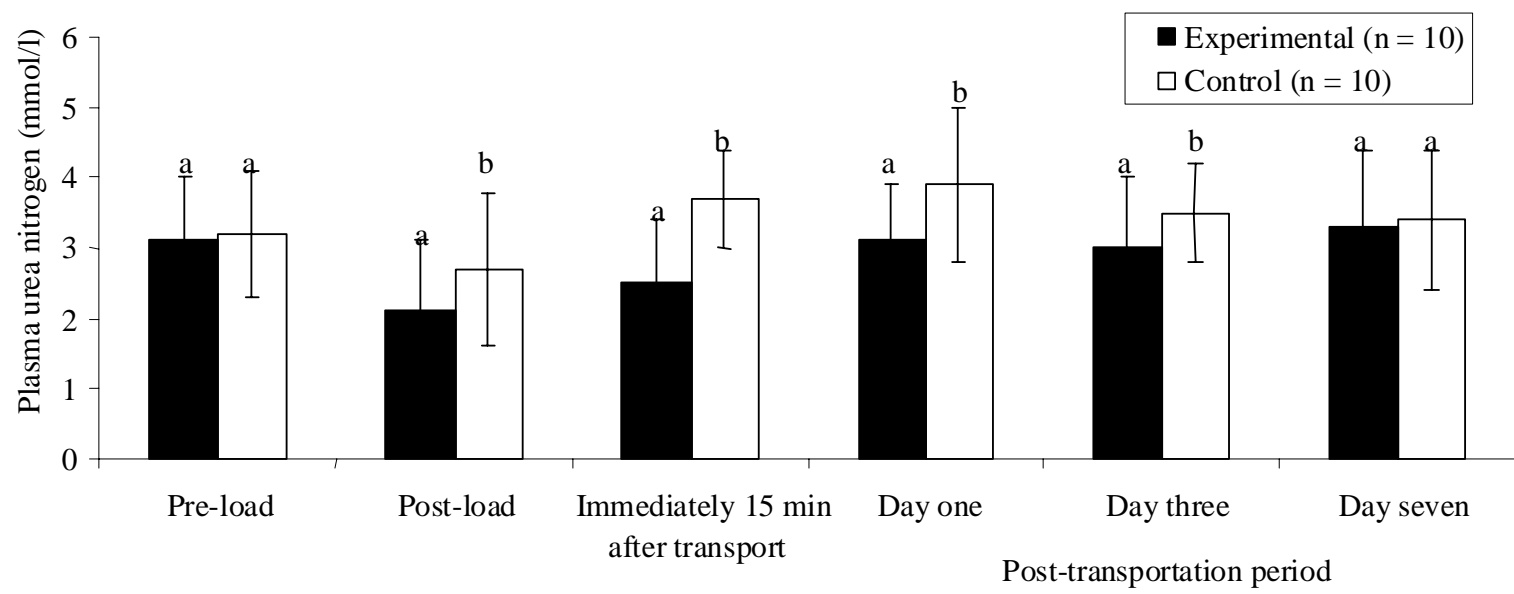

Fig 4: Fluctuations in plasma urea nitrogen $(\mathrm{mmol} / \mathrm{l})$ in the experimental and the control goats pre- and posttransportation. $a, b=$ Bars with different alphabets are significantly $(P<0.05)$ different.

Effects of administration of ascorbic acid and transportation on muscular soreness of goats

There was no stiffness of gait or pain response (score 1) in the experimental or the control goats before transportation. However after unloading, the goats were reluctant to walk. Twelve, 36, and 60 hours posttransportation period, the percentage number of goats that developed DOMS and it severity are shown in Table 1 . The results showed that control goats had significantly $(\mathrm{P}<0.05)$ severe DOMS compared with the experimental goats. Values returned to base-line after $12 \mathrm{~h}$ and $60 \mathrm{~h}$ of post-transportation period in the experimental and control goats, respectively (Table 1 ).

\section{Serum biochemistry}

Aspartate aminotransferase

Handling and loading decreased the serum activity of AST from pre-loading values of $38.9 \pm 4.5 \mathrm{iu} / \mathrm{l}$ and $39.0 \pm 3.6 \mathrm{iu} / \mathrm{l}$ to post-loading values of $35.7 \pm 5.7 \mathrm{iu} / \mathrm{l}$ 


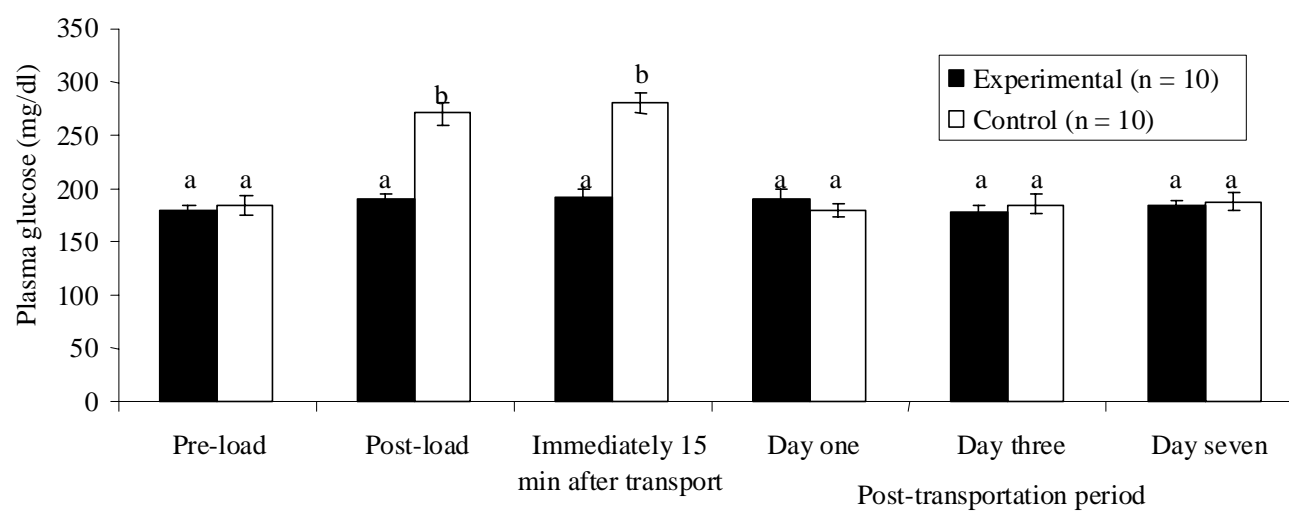

Fig 5: Fluctuations in plasma glucose concentration ( $\mathrm{mg} / \mathrm{dl})$ in the experimental and the control goats pre- and posttransportation. $a, b=$ Bars with different alphabets are significantly $(P<0.05)$ different.

and $36.9 \pm 4.0 \mathrm{iu} / \mathrm{l}$ in the control and experimental goats, respectively. The values did not differ $(\mathrm{P}>0.05)$ between the groups. However, after transportation serum AST activities increased $(\mathrm{P}<0.05)$ in the control, while in the experimental goats they did not change. In the control goats AST activities were returned to base-line values $36 \mathrm{~h}$ after the transportation (Figure 1).

Alanine aminotransferase

Alanine aminotransferase (ALT) activity in the control goats increased significantly $(\mathrm{P}<0.05)$ from base-line value of $59.8 \pm 2.5 \mathrm{iu} / \mathrm{l}$ to $69.7 \pm 7.8 \mathrm{iu} / \mathrm{l}$ post-loading and further to a peak value of $81.5 \pm 6.0 \mathrm{iu} / \mathrm{l}$ after transportation. In the experimental goats there was no significant $(\mathrm{P}>0.05)$ increase from the post-loading value of $64.9 \pm 6.7 \mathrm{iu} / \mathrm{l}$ after the transportation. Baseline concentrations were restored $36 \mathrm{~h}$ after the transportation in the control goats (Figure 2).

Creatine phosphate kinase

Figure 3 show changes in CPK activity pre-and postloading. Serum CPK activity in the control goats, increases during loading $(91.5 \pm 8.5 \mathrm{iu} / \mathrm{l})$ and maximum values were reached immediately after transportation $(95.7 \pm 10.5 \mathrm{iu} / \mathrm{l})$ and then decrease gradually to baseline values at $60 \mathrm{~h}$ after transportation. In the experimental goats who had supplemented with AA, activity of CPK not showed changes.

\section{Plasma urea}

Figure 4 shows changes in plasma urea concentration pre-and post-loading. There was a decrease in the concentrations of urea from the pre-loading values of $3.1 \pm 0.9 \mathrm{mmol} / \mathrm{l}$ and $3.2 \pm 0.9 \mathrm{mmol} / \mathrm{l}$ and to postloading values of $2.1 \pm 0.2 \mathrm{mmol} / \mathrm{l}$ and $2.7 \pm 0.5$ $\mathrm{mmol} / \mathrm{l}$ recorded in the experimental and the control goats, respectively. During transportation the values increased significantly $(\mathrm{P}<0.05)$ in control goats to $3.7 \pm 0.7 \mathrm{mmol} / \mathrm{l}$ post-transportation and further rose to $3.9 \pm 1.1 \mathrm{mmol} / \mathrm{l} 12 \mathrm{~h}$ after transportation. The baseline values were restored $60 \mathrm{~h}$ post-transportation. In the experimental goats the urea concentration was not affected by loading or transportation.

\section{Glucose}

Plasma glucose concentration in the control goats increased rapidly $(\mathrm{P}<0.01)$ post-loading $(270 \pm 10.0$ $\mathrm{mg} / \mathrm{dl})$ and immediately after transportation (280 \pm 9.4 $\mathrm{mg} / \mathrm{dl}$ ) (Figure 5) from the pre-loading value of $184 \pm$ $8.9 \mathrm{mg} / \mathrm{dl}$. In the experimental goats, the increase postloading values (189 $\pm 5.9 \mathrm{mg} / \mathrm{dl})$ was not significantly $(\mathrm{P}>0.05)$ higher than the pre-loading values (180 \pm $4.7 \mathrm{mg} / \mathrm{dl})$. Post-transportation, the concentration of glucose in the experimental goats was higher than that of the pre-loading, but lower than the corresponding value obtained in the control goats. The elevated glucose level in the control and experimental goats was returned to the pre-loading value $12 \mathrm{~h}$ after the transportation.

\section{Discussion}

The average temperature recorded during the period of the journey was outside the thermo neutrality zone (22$35{ }^{\circ} \mathrm{C}$ ) established for goats in the tropics [55]. The result demonstrated that the high AT, RH, solar radiation, and the hot-dry air blowing through the goats, coupled with the concomitant effects of road transportation stress did not favour the transportation of the goats, especially during the afternoon hours of the day when the meteorological values attained their 


\title{
Effect of ascorbic acid on muscles of transported goats
}

\author{
European Journal Translational Myology - Basic Applied Myology 2010; 1 (4): 193-203
}

highest peak values above the upper limit of supportability for the goats. At this period of the day heat stress was apparent, and posed a significant threat to the homeostatic mechanisms of the goats.

The pain response on palpation of the lumber muscles and the stiffness of gaits manifested by the goats 12 and $36 \mathrm{~h}$ post-transportation period indicated that muscular soreness was developed by the goats, especially in the control goats. This type of muscle soreness is known as delayed-onset muscular soreness (DOMS), and is common in human and horses after un-accustomed exercise $[38,51,53]$.

In the present study, the process of rounding up, handling and loading, novelty of environment, and the to- and fro- movement induced in the goats by the vehicle movement, noise, vibration, the agonistic attack, escape attempt, mounting and long standing or lying down, extreme environmental conditions and confinement altered the metabolism of muscles tissues, apparently resulting in DOMS. Besides, the fact that the goats were raised extensively, not accustomed to handling and confinement in which they were subjected during 12 hours of transportation and another 12 hours of post-transportation in holding, may have exacerbated the stress on muscular activities, as reported by several authors, leading to an increase in free radicals formation and ROS of the body [6,18,53]. Animals that are transported under heat stress conditions, as experienced in the present study may develop DFD meat brought about by lack of glycogen in the muscle for energy provision. DFD meat is an undesirable meat quality, reported to occur regularly in transported pigs and ruminants [4,23,24,28,45,60,61]. The less DOMS observed in the experimental goats administered with AA, demonstrated that AA reduced the depletion of muscle glycogen, thus enhanced the ability of the goats to withstand transportation stress factors. Furthermore, AA is known to enhance the synthesis of collagen [8,53], a major component of connective tissue, which is found mostly around musculo-tendinous junctions and known to be degraded by free radicals [22,53]. Similarly AA at higher doses is reported to be an anti-inflammatory agent [27]. The result obtained from this study demonstrated for the first time that AA reduced the incidence of DOMS in transported goats, therefore may be used to improve the quality of meat obtained from goats subjected to long period of road transportation under adverse climatic conditions, especially if the animals are to be slaughtered immediately after the transportation. Further study may be required in this area by using a larger number of animals.

The increase activity of muscle enzymes such as AST, ALT and CPK that we found in blood during the trial, following the handling, loading and transportation, shows an increase in muscle cell permeability and cell damage. These enzymes appear elevated in many stressed animals as a result of physical stress, transportation or exercise and capture myopathy, which often lead to tearing of muscle fibres $[6,11,20,29,53]$. When muscle activity begins, blood flow increases but is intermittent. Blood flow decreases as the muscle contracts because of the compression of vessels, and increases during relaxation, a process called the muscle pump. The muscle pump is active when the animal is walking or running, but it is inactive when the animal is immobilized by physical or chemical restraint or is standing in a confined area. In most situations, the muscles of frightened animals that are not running are in a relatively isometric state of contraction, just as it is during transportation. This hinders blood flow into the muscles, which subsequently leads to poor tissue perfusion, decreased heat dissipation, hypoxia and death of the cells and tissue [43]. Animals slaughtered under such conditions may develop DFD meat and may have higher ultimate $\mathrm{pH}$, which is not always ideal for conversion of muscle to meat $[28,45]$. The increase in CPK up to $36 \mathrm{~h}$ of post-transportation period suggested that the goats suffered muscular damage and were excessively fatigued up to the $36 \mathrm{~h}$ post-transportation. The post-transportation recovery period of CPK in this study were longer than the 3 and $24 \mathrm{~h}$ recovery periods reported by Kannan et al. [30] and Galipalli et al. [20], during transportation of goats for 2.5 and $6 \mathrm{~h}$, respectively. The present result showed that long duration of road transportation of goats had a prolong effect on the goats muscles. Kannan et al. [29] observed that the increase of CPK activity in goats is higher in loading and unloading operations compared to the effects determined by the transport itself and feed deprivation. It was also reported that high CPK activity post-transportation may be associated with overcrowding, agonistic behaviours and bruising, especially during prolong holding and feeding at lairage [11,17,30].

Results obtained from the experimental goats administered with AA indicated that the increase in the enzymes were slightly higher only during handling and loading. Post-transportation period, the values obtained were not significantly $(\mathrm{P}>0.05)$ different from the pretransportation or pre-loading values. This indicated that AA reduced the permeability of cell membrane and prevented the hypoxia encountered by the muscles that were in isometric contraction during the journey. This finding further indicated that oxygen supply to muscles was not impaired in AA-treated goats, thus reducing the risk of tissue hypoxia and consequent oxidative damage. Furthermore, AA was able to repair tissue injuries often encountered during handling and loading of goats. This finding was in agreement with those of Balz [8], Tauler et al. [62], Powers and Jackson [53] and Minka and Ayo [2010], who showed 


\section{Effect of ascorbic acid on muscles of transported goats}

European Journal Translational Myology - Basic Applied Myology 2010; 1 (4): 193-203

that AA regulates blood circulation and permeability of cell membranes, enhances synthesis of collagen, responsible for tissue building and scavenging of free radicals or ROS brought about by hypoxia through the donation of free molecule of hydrogen.

Handling and loading of goats resulted in a decrease in plasma urea, especially in the experimental goats $(\mathrm{P}<$ 0.05). However, in the control goats after transportation the increased $(\mathrm{P}<0.05)$ in plasma urea indicated an increase in protein breakdown. This may be as a result of increase in cortisol concentration and prolong food deprivation which caused breakdown of some protein and nucleic acids in muscles during the stressful transportation conditions [35, 29]. The fact that baseline value of urea was returned to only after $60 \mathrm{~h}$ post-transportation indicated the severity of catabolism during post-transportation period. The present findings agree with those of Knowles et al. [35] in cattle, who reported an increase in urea from pretransportation values of 1.5 to $3.6 \mathrm{mmol} / \mathrm{l}$ posttransportation during short journey; while during 36-h journey, the increase attained a maximum value of 4.3 $\mathrm{mmol} / \mathrm{l}$, and the pre-transportation values were restored only after 72 hours post-transportation. The fact that the pre-transportation value was restored $60 \mathrm{~h}$ posttransportation period indicates that the general metabolism of the goats was largely returned to normal by this time. Similar results were obtained in transported calves [34] and roe deer [43]. The nonsignificant increase in urea concentration posttransportation in goats administered with AA indicated that AA reduced the process of tissue catabolism occurring during the stressful conditions. The result is in agreement with the findings of Balz [8], and Tauler et al. [62], showing that during normal metabolism and stress, AA protects indispensable molecules in the body like protein, DNA and RNA from damage by free radicals or ROS. The present result demonstrated that the products of catabolism released in the body due to handling, loading and transportation were reduced considerably because AA protected the tissue from damage.

The increase in plasma glucose follows post-loading and immediately after transportation, especially in the control goats may be due to increase in glycogenolysis, stimulated by increased secretions of catecholamine and glucocorticoid hormones which are under the control of the sympathetic nervous system $[35,49]$. Thus, during the stressful period of transportation the sympathetic nervous system was activated and it triggered the secretion of hormones responsible for the stimulation of glycogenolysis for more production of glucose from the liver and muscles into systemic circulation [29,32,54]. The restoration of pretransportation glucose level $12 \mathrm{~h}$ after the journey obtained in the present study was longer than the findings of Nwe et al. [46] and Kannan et al. [29], who reported restoration of pre-transport glucose level in goats 3 and 6 h respectively, post-transportation. Nwe et al. [46] and Kannan et al. [28, 29], observed that as a response to stress, elevation of glucose concentration was preceded by an elevation of cortisol concentration. Therefore, Sanhouri et al. [56] and Parker et al. [47] reported that plasma glucose concentration may be useful as an indicator of the intensity of stress. Aoyama et al. [3] showed that transportation almost doubled the plasma glucose levels in goats within 15 min, which was caused by an increase in catecholamine secretion from adrenal medulla. It therefore appears that AA inhibited the secretion of catecholamine from the adrenal medulla. AA has been found to be a vitaminergic neurotransmitter it is present in high concentration in the hypothalamus, and is released into the extracellular space by neuronal activity were it inhibit the activation of luteinizing hormone releasing hormone (LH-RH) from the LH-RH terminals located in the hypothalamus, which is known to induce the release of cortisol, the chief hormone of stress [31]. Since body AA was presumed to be depleted during the transportation, its supplementation in the present study may have refueled the depleted AA in the body, consequently improving the body adaptational capability. This hypothesis requires further investigation.

It is known that ruminant generally display lower blood glucose levels compared to non-ruminant animals. This situation usually contributes to a lower muscle glycogen content and rate of muscle glycogen depletion, which in part is one of the causative factors in DFD meat $[13,28,29]$. In AA-treated goats the values of glucose post-transportation was not different from the pre-loading value which suggested that AA decreased glycogenolysis, thus inhibiting the release of glucose from the liver and muscles.

The results of DOMS and serum enzymes obtained post-transportation, showed that goats that developed severer DOMS had higher values of serum biochemical activities, while goats with mild DOMS had lower values of serum enzymes. The result, for the first time, suggested that DOMS may be used in predicting the extent of muscular damage in transported goats before any laboratory analysis is done. Thus, DOMS may be employed as a diagnostic tool in long distance road transportation stress in goats. Further investigation may be required in this area to evaluate the effects of different journey durations and AA administration on instrumental and sensorial qualities of the goats' meat.

It conclusion, $12 \mathrm{~h}$ of road transportation was stressful to the goats, and resulted in muscular damage, which lasted for $60 \mathrm{~h}$ after transportation. AA may be used to reduce or eliminate fatigue, muscular damage and the incidence of dark-cutting meat, which is a major problem in transported animals intended for slaughter. 


\section{Effect of ascorbic acid on muscles of transported goats}

European Journal Translational Myology - Basic Applied Myology 2010; 1 (4): 193-203

The result is of economic importance to meat industries and consumers, especially in countries where standard abattoirs and slaughter houses with designated lairages for resting transported animals before slaughter are completely lacking. In this region of the world, animals are transported directly to the market and are purchased and slaughtered immediately on arrival at slaughter slabs without being properly rested. The administration of AA to goats prior to transportation may therefore, reduce posttransportation lairage duration, fatigue, muscular damage, and consequently, enhance meat quality in the market.

\section{Acknowledgements}

The authors are grateful to the Laboratory Staff of the College of Agriculture and Animal Science, ABU, Mando-Kaduna for their technical assistances.

\section{Corresponding Author}

Ndazo S Minka. College of Agriculture and Animal Science, P.M.B, 2134. Ahmadu Bello University, Mando-Kaduna, Nigeria. E-mail: mnsalka@yahoo.com

\section{References}

[1] Ali BH, Al-Qarawi AA, Mousa HM. Stress associated with road transportation in desert sheep and goats, and the effect of pre-treatment with xylazine or sodium betamine. Res Vet Sci 2006; 80: 343-348.

[2] Anon. European Union Council Directive 91/628 on the Welfare of Animals in Transit as amended by Directive. 1991, 95/29.

[3] Aoyama M, Negishi A, Abe A, Maejima Y, Sugita S. Sex differences in stress responses to transportation in goats: effects of gonodal hormones. Anim Sci J 2003; 74: 511-519.

[4] Apple JK, Minton JE, Parson KM, Unruh JA. Influence of repeated restraint and isolation stress and electrolyte administration on pituitary-adrenal secretions, electrolytes and other blood constituents of sheep. J Anim Sci 1993; 71: 7177.

[5] Atkinson PJ. Investigation of the effects of transport and lairage on hydration state and resting behaviour of calves for export. Vet Rec 1992; 130: 413 - 416.

[6] Averos A, Martin S, Riu M, Serratosa J, Gosalvez LF. Stress response of extensively reared young bulls being transported to growing-finishing farm under Spanish summer commercial conditions. Livest Sci 2008; 119: 174-182.

[7] Ayo JO, Minka NS, Mamman M. Excitability scores of goats administered ascorbic acid and transported during hot dry conditions. J Vet Sci 2006; 7: 127-131.
[8] Balz F. Vitamin C intake. Nutri Dis 2003; 14: 18.

[9] Broom DM. The effects of land transport on animal welfare. Rev Sci Off Int Epiz 2005; 24: 683-691.

[10] Brown SN, Knowles TG, Edwards JE, Warriss PD. Behavioural and Physiological responses of pigs to being transported for up to 24 hours followed by six hours recovery in lairage. Vet Rec 1999a; 145: 421-426.

[11] Brown SN, Knowles TG, Edwards JE, Warris PD. Relationship between food deprivation before transport and aggression in pigs held in lairage before slaughter. Vet Rec 1999b; 145: 630 - 634.

[12] Bushell A, Klenerman L, Davies H, Grierson I, Jackson M. Ischaemia-repurfusion induced muscle damage. Protective effect of corticosteroids and antioxidants in rabbits. Acta Orthoped Scand 1996; 67: 393-321.

[13] Cole NA, Philips WA, Hutchson DP. The effect of pre-fast on transport in calves. J Anim Sci 1987; 63: 1015-1020.

[14] Consiglio Nazionale delle Ricerche del National Accademie. Vitamins. Nutrient Requirements of dogs and cats. Animal Nutrition Series, Washington DC, National Academies Press, 2006, pp. 234-235.

[15] Farm Animal Welfare Council ((FAWC). Farm animal at slaughter or killing Part 1, London, Defra Publications, 2003.

[16] Fazio E, Ferlazzo, A. Evaluation of stress during transport. Vet Res Comm, 2003; 27: 519-524.

[17] Ferguson DM, Warner RD. Have we underestimated the impact of pre-slaughter stress on meat quality in ruminants? Meat Sci, 2008; 80: 12-19.

[18] Fitzgerald RF, Stalder KJ, Matthews JO, Kaster CMS, Johnson AK. Factors associated with fatigued, injured, and dead pig frequency during transport and lairage at a commercial abattoir. J Anim Sci 2009; 87: 1156-1166.

[19] Fitzpatrick J, Scott M, Nolan A. Assessment of pain and welfare in sheep. Small Rum Res 2005; 62: 55-61.

[20] Galipalli S, Gadiyaram KM, Kouakou B, Terrill TH, Kannan G. Physiological responses to preslaughter transportation stress in Tascosupplemented goats. S/Afr J Anim Sci 2004; 34: 198-200.

[21] Grandin T. Behavioural Principles of Livestock Handling, American Registry of Professional Animal Scientists, 2002, pp.1-11.

[22] Greenwald RA, May MW. Degradation of cartilage proteoglycans and collagen by super oxide radical. Arthritis Rheumatol 1976; 19: 799. 


\section{Effect of ascorbic acid on muscles of transported goats}

European Journal Translational Myology - Basic Applied Myology 2010; 1 (4): 193-203

[23] Gregory NG. Animal welfare at markets and during transport and slaughter. Meat Sci 2008; 80: 2-11.

[24] Gupta S, Earley B, Crowe MA. Effect of 12 hour road transportation on physiological, immunological and haematological parameters in bulls housed at different space allowance. Vet J 2007; 173: 605-616.

[25] Hesta M, Ottermans C, Krammer-Kukas S, Zentek J, Hellweg P, Buyse J, Janssen GPJ. Effect of vitamin $\mathrm{C}$ supplementation in healthy dogs on antioxidant capacity and immune parameters. J Anim physiol Anim Nutri 2009; 93: 26-34.

[26] Ibironke AA, McCrindle CME, Adejuwon TA, Cadmus SIB. Losses associated with mortality of cattle and camels during transportation to OkoOba abattoir, Lagos, Nigeria. Eur J Translational Myology - Basic Appl Myology 2010; 1: 13-16.

[27] Kaminski M, Boal R. An effect of ascorbic acid on delayed-onset muscular soreness. Pain, 1982; 50: 317.

[28] Kannan G, Kouakou B, Terrill TH, Gelaye S. Endocrine, blood metabolite, and meat quality changes in goats as influenced by short-term, preslaughter stress. J Anim Sci 2003; 81: 1499-1507.

[29] Kannan G, Terrill TH, Kouakou B, Gelaye S, Amoah EA. Simulated preslaughter holding and isolation effects on stress responses and liveweight shrinkage in meat goats. J Anim Sci 2002; 80: 1771-1780.

[30] Kannan G, Terrill H, Kouakou B, Gazal OS, Gelaye S, Amoah EA, Samake S. Transportation of goats: Effects on physiological stress responses and liveweight loss. J Anim Sci 2000; 78: 14501457.

[31] Karanth S, Yu WH, Walczewska A, Mastronardi C, McCann M. Ascorbic acid acts as an inhibitory transmitter in the hypothalamus to inhibit stimulated luteining hormone-releasing hormone release by scavenging nitric oxide. Proc Nat Am Sci 2000; 97: 1891-1896.

[32] Kent JE, Ewbank R. The effect of road transportation on the constituent and behaviour of calves. 1. Six months old. Br Vet J 1983; 139: 228-235.

[33] Knowles TG. A review of post-transport mortality among young calves. Vet Rec 1995; 137: 406-407.

[34] Knowles TG, Brown SN, Edwards JE, Philips AJ, Warriss PD. Effect on young calves of a one-hour feeding stop during a 19-hour road journey. Vet Rec 1999a; 144: 687-692.
[35] Knowles TG, Warriss PD, Brown SN, Edwards JE. Effects on cattle of transportation by road for up to 31-hours. Vet Rec 1999b; 145: 575-582.

[36] Lopez-Olvera J, Marco I, Montane J, Lavin S. Transport stress in Southern chamois (Rupicapra pyrenaica) and its modulation by acepromazine. Vet J 2006; 1720: 347-355.

[37] Lykkesfeldt J, Svendsen O. Oxidants and antioxidants in disease: Oxidative stress in farm animals. Vet J 2007; 173: 502-511.

[38] Mills PC, NG, JC, Thornton J, Seawright AA, Auer E. Exercise-induced connective tissue turnover and lipid peroxidation in horses. Br Vet J, 1994; 150: 53-63.

[39] Minka NS, Ayo JO. Effects of loading behaviour and road transportation stress on traumatic injuries in cattle transported by road during the hot-dry season. Livest Sci 2007a; 107: 91-95.

[40] Minka NS, Ayo JO Physiological responses of transported goats treated with ascorbic acid during the hot-dry season. Anim Sci J 2007b; 78: 164-172.

[41] Minka NS, Ayo JO. Assessments of the stresses imposed on adult ostriches (Struthio camelus) during handling, loading, transportation and unloading. Vet Rec 2008; 162: 846-851.

[42] Minka NS, Ayo JO. Physiological responses of erythrocytes of goats transported for twelve hours and the modulation role of ascorbic acid. $\mathrm{J}$ Vet Med Sci 2010; 85: 389-393.

[43] Montane J, Marco I, Lopez-Olvera J, Manteca X, Lavin S. Transport stress in roe deer (Capreolus capreolus): Effect of short acting antipsychotic. Anim Welfare 2002; 11: 295-303.

[44] Moolchandani A, Sareen M, Vaishnav M. Influence of restraint and isolation stress on plasma cortisol in male karakul sheep. Vet Arhiv, 2008; 78: 357-362.

[45] Muchenje V, Dzama K, Chimonyo M, Strydom PE, Raats JG. Relationship between pre-slaughter stress responsiveness and beef quality in three cattle breeds. Meat Sci 2009; 81: 653-657.

[46] Nwe TM, Hori E, Manda M, Watanabe S. Significance of catecholamines and cortisol levels in blood during transportation stress in goats. Small Rum Res 1996; 20: 129-135.

[47] Parker AJ, Hamlin GP, Coleman CJ, Fitzpatrick LA. Dehydration in stressed ruminants may be the result of a cortisol-induced diuresis. J Anim Sci 2003a; 81: 512-519.

[48] Parker AJ, Hamlin GP, Coleman CJ, Fitzpatrick LA. Quantitative analysis of acid-base balance in Bos indicus steers subjected to transportation of long duration. J Anim Sci 2003b; 81: 1434-1439. 


\section{Effect of ascorbic acid on muscles of transported goats}

European Journal Translational Myology - Basic Applied Myology 2010; 1 (4): 193-203

[49] Parker AJ, Dobson GP, Fitzpatrick LA. Physiological and metabolic effects of prophylactic treatment with the osmolytes glycerol and betaine on Bos indicus steers during long duration transportation. J Anim Sci 2007; 85: 2916-2923.

[50] Perez M, Palacio J, Santolaria MP, Acena MC, Chacon G, Gascon M, Calvo JH, Zaragoza P, Beltran JA, Garcia-Belenguer S. Effect of transport time on welfare and meat quality in pigs. Meat Sci 2002; 61: 425-433.

[51] Piccione G, Fazio F, Giannetto C, Assenza A, Caola G. Oxidative stress in thoroughbreds during official 1800-meter races. Vet Arhiv 2007; 77: 219-227.

[52] Plyaschenko SI, Sidorov VT. Stresses in farm animals. Moscow, Agropromizdat, 1987 (in Russian).

[53] Powers SK, Jackson MJ. Exercise-induced oxidative stress: Cellular mechanisms and impact on muscle force production. Physiol Rev 2008; 88: 1243-1276.

[54] Rajion MA, Soat IM, Zulkifli I, Goh YM. The effects of road transportation on some physiological stress measures in goats. AsianAustr J Anim Sci 2001; 9: 1250-1252.

[55] Richardson C. Lowering stress in transported goats. Ontario Ministry of Agriculture and FoodLivestock Technology Branch, Northern Ontario Regional Office. 2002.

[56] Sanhouri AA, Jones RS, Dobson N. Prazosin and propranolol and the stress response to transport in male goats; a preliminary study. J Vet Pharmacol 1991; 14: 421-425.
[57] Schaefer AL, Jones SDM, Stanley RW. The use of electrolyte solution for reducing transport stress. J Anim Sci 1997; 75: 258 - 265.

[58] Schaefer AL, Jones SDM, Tong AKW, Young BA. Effects of transport and electrolyte supplementation on ion concentration, carcass yield and quality in bulls. Can J Anim Sci 1990; 70: 107-114.

[59] Stull CL, Rodiek AV. Physiological responses of horses to 24 hours of transportation using a commercial van during summer conditions. J Anim Sci 2000; 79: 1458-1466.

[60] Tarrant PV. The occurence, causes and economic consequences of dark-cutting in beef a survey of current information. In: Hood, D.E., Tarrant, P.V. (Eds), The Problem of Dark-Cutting in Beef. The Hague, Martinus Nizhoff, 1981, pp. 3-36.

[61] Tarrant PV, Grandin T. Transportation of cattle by road. In T. Grandin (Ed.). Livestock Handling and Transport, Wallingford, CAB International, 1993, pp. 109-126.

[62] Tauler P, Aguilo A, Gimeno I, Fuentespis E, Tur $\mathrm{JA}$, Pons A. Influence of vitamin C supplementation on endogenous antioxidant defense during exhaustive exercise. Eur J Physiol 2003; 440: 658-664.

[63] Terlouw EMC, Rybarczyk P. Explaining and predicting differences in meat quality through stress reactions at slaughter: The case of large white and duroc pigs. Meat Sci 2008; 79: 795805.

[64] Warriss PD. Optimal lairage time and conditions for slaughter pigs. A review. Vet Rec 2003; 153: 170-176. 